\title{
Bringing sustainable urban planning down to earth through food: the experience of the food transects of Grenoble and Caen
}

\author{
Jennifer Buyck ${ }^{1}$ (D) Aurore Meyfroidt ${ }^{1} \cdot$ Caroline Brand $^{2} \cdot$ Gabriel Jourdan $^{3}$
}

Received: 25 February 2019 / Accepted: 29 April 2021/ Published online: 16 June 2021

(C) The Author(s) 2021

\begin{abstract}
Our contribution aims at pointing out how the food issue challenges metropolitan areas while at the same time identifying potential for sustainable urban planning. To that end, we investigate to what extent taking into account agricultural and food-related issues enables to rethink urban planning which is usually qualified as sustainable. Our analysis will be based upon the two French urban regions of Grenoble and Caen where participatory research was conducted through collective and prospective walks. These urban explorations, which provide insights on metropolitan spaces and the interrelations that underlie them, underly the disconnections of contemporary urban planning with the inhabitants, their vital needs and, more generally, the soil, while highlight working paths for a more nourishing, meaningful and rooted urban planning. By considering urban planning through the scope of agri-food stakes, we contribute then to the renewal of urban concepts and thus highlight three workshops aiming at further developing sustainable urban planning issues and tools.
\end{abstract}

Keywords Agriculture · Food - Metropolitan areas - Transect - Sustainable urban planning · Agro-ecological urbanism

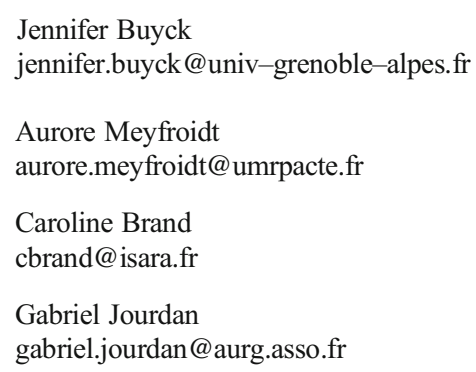

Extended author information available on the last page of the article 


\section{Introduction}

Although food is an emerging, even orphaned subject in French urban and metropolitan planning policies, it does not leave the inhabitants indifferent - quite the contrary. This is the observation shared by all the participants of the Grenoble transect (Tixier, 2016) on 23 May 2018. On that day, twenty researchers, associations and agricultural, food and/or urban professionals met to cross the Grenoble metropolitan area and meet the places of production, housing, commercialization etc. and its inhabitants with the aim of grasping the relationship between the urban agglomeration and its agricultural and food systems. The people we met during this action-research day had a lot to say and to teach us about their way of eating, of designing agricultural and food systems (Horton et al., 2017) and of considering the future of urban spaces in the city centre as well as on the periphery. A similar action-research study conducted in Caen the following week corroborates this initial observation.

Organized as part of the PSDR FRUGAL research project, the aim of these two action-research projects is to highlight how the food issue is challenging the metropolitan areas while at the same time identifying potential for renewal towards sustainability. The ambition of this article relies precisely in this twofold quest: that of a better knowledge of metropolitan areas and the relations that underlie them (particularly food) and that of a renewal of the issues and tools of territorial planning. To what extent does the integration of agricultural and food issues contribute to the renewal of territorial planning and its objective of sustainability? In other words, this is the research question on which our analysis is based.

The collective and in situ explorations carried out in Grenoble and Caen precisely inform us about the disconnections of contemporary - so-called sustainable urbanism with the inhabitants, their vital needs and more generally the soil. The inhabitants we met, the initiatives analysed and the debates generated also raise avenues for a better consideration of agri-food issues (Brand, 2015). What are they based on? And towards what are they heading? What could be the new nature of sustainable urban planning that would take up the agri-food issues? And what would the territorial planning tools behind it look like?

Three chapters structure our response to these questions. The first section focuses on the international, national and local challenges of agricultural and food systems regarding urban issues and shows how urban planning is being challenged by the recent consideration of agri-food issues. The second explains the method implemented by contextualizing the approaches and describing the operational methods of this actionoriented research. The third describes the results of this approach and presents the phenomena of the disconnection of contemporary urban planning with the inhabitants, their vital needs and more generally the soil, while highlighting directions for a more foster, meaningful and anchored urban design. The conclusion, finally, clarifies the importance of taking into account the agri-food sector in order to "land" the urban and its planning system (Latour, 2017).

Our aim is to show and reflect on the interactions between agricultural and food systems within the urban agglomerations of Grenoble and Caen. Sketching out the possibilities for development and projects carried by both residents and local authorities is just as important. This enables us to rethink proximity systems in their complex interplay of scales ranging from the local to the globalized production chains. Our main 
hypothesis is therefore that, through the multi-sited approach of transects, it is possible to "land" sustainable urban planning, by paying attention to food and agricultural areas, to revitalize or even rethink territorial planning and to reveal ongoing reorganization that is a vector of sustainability. This main hypothesis is broken down into three hypotheses which are developed in the paper. Beyond the potential for comparison offered by Grenoble and Caen, what is very interesting in the perspective of these two case studies is the plurality of agricultural, food and urban situations identified. Although similarities can be highlighted, it is the differences, sometimes substantial, that are surprising. They remind us that the transition of metropolises and urban planning towards greater sustainability is not univocal and that such sustainability can only be built as situated knowledge.

\section{Food-proofing sustainable urban planning: a retrospective of a recent agenda}

Here we seek to put into perspective the issues involved in the evolution of agriculture, food and metropolises by showing the salient points of their interactions. Our analysis offers a retrospective overview of these links and explains the recompositions in progress, particularly in the articulation of these three areas. This is done by looking at the spatial dynamics of interactions, the place of agricultural and food issues in the system of action of territorial development and planning, particularly in urban areas, and finally by illustrating our argument with the situations of Grenoble and Caen.

\section{Agriculture, food and living spaces: a chronicle of marginalization}

The period that began after the Second World War represented a major rupture in the relationship between agriculture, food and cities. In order to understand what is at stake today, a historical retrospective of these relations gives an insight into the evolution of the spatial dynamics of interaction.

Analyses in terms of territorial metabolism shed interesting light on these developments by looking at the material flows that link them. Until the end of the nineteenth century, agrarian systems and living areas interacted strongly and participated in a territorial metabolism operating in circularity (Barles, 2010; Billen et al., 2012). Spatially, relations of proximity are established (Malassis, 1997), with the products and wastes of one production system becoming the resources of another. For example, human and urban wastes are valorised in proximity agriculture. Polyculture-livestock farming is an emblematic, spatially inscribed form of this virtuous interaction (Noé, 2018). And conversely, inhabited areas are shaped by agricultural and food systems. In the spatial structure of the "organic city" (Steel, 2009), food markets occupy the central places and structure the life of the neighbourhoods, while the toponymy of the places indicates the presence of the food trades. Under the combined effects of urbanization, industrialization and their corollaries (transport revolution, technical progress in food preservation and processing, development of chemical inputs), the twentieth century is the century of the linearization of flows within the territorial metabolism and therefore of the break of the virtuous cycle between city, agriculture and food. This rupture culminated at the end of the Second World War. A double disconnection then occurs. 
We can observe a social distancing of the links between the food and the consumer and a spatial disconnection between the production space, the rural area and the consumption space, which is now mostly urban. On the one hand, agriculture has gradually become part of a mode of development that has opened up market prospects beyond the local market (Knapp, 1930). It has become autonomous from surrounding living areas and local food needs in the name of the imperative of productivity and profitability following the emergence of the capitalist regime. This is the advent of the agroindustrial system (Marsden \& Murdoch, 2006; Rastoin \& Ghersi, 2010). On the other hand, the city has become detached from geographical constraints and dependence on local agricultural food (Steel, 2009) to open up to global supply chains through an autonomized agricultural and agri-food system. The hinterland of cities has become global. In addition to this, the advent of the "urban century" has led to the disconnection of relations with agriculture and food (Bellows \& Nasr, 2010: 18). At the end of the nineteenth century, the city wanted to control flows and began to distance itself from them, which was gradually pushed to the fringes of the city.

This linearization of flows and disconnection raises the question today: food crises and ecological issues are changing the behaviour of individuals while, on a global scale, we are constantly highlighting the major issues that frame thinking about food for a planet that is urbanizing and whose population is experiencing an exponential growth curve (Bricas, 2017). Within cities, this disconnection has generated the emergence of urban forms favourable to obesity (Sui, 2003) and discontinuities such as food deserts (Cummins et al., 2008). And, in a contrasting interplay with the so-called conventional food system, failures and new practices and expectations generate a pendulum swing that reactivates local and regional geographies in the shaping of production and consumption systems (Blay-Palmer, 2008; Kneafsey et al., 2008). This reactivation covers alternative forms that have in common to be at odds with the generic and aspatial character of the agro-industrial system. The urban appears as a catalyst in the expression of these new practices whose emergence is not without controversy (Tornaghi 2014).

From this, we formulate a first hypothesis according to which food and agricultural issues are currently disconnected from the city, which has become a metropolis, and from its development - whether it is described as sustainable or not. Bringing agriculture and food out of their invisibility means opening up to the renewal of agriculture and food as well as of the city itself.

\section{Renewing the interactions between agriculture, food and cities: putting on food the urban agenda}

These dynamics of spatial interactions resonate with the place attributed to agricultural and food issues in the action system of land use and planning.

Until the end of the nineteenth century, local public authorities intervened in the food system of their territory. A diversity of forms of intervention (Brand et al., 2017) reflected the fundamental nature of agricultural and food systems for the urban system. However, although vital for the functioning of territories and strategic for urban governments, cities gradually abandoned control over their food. And, even if their role as regulators has never disappeared, particularly in terms of food safety, from the end of the nineteenth century, governance was partly transferred to the national and 
international levels and to private agri-food actors. There is thus a disengagement: territorial authorities still intervene in food but for reasons far from the sole function of feeding. The strategic vision of food is replaced by an approach of economic development of a sector of activity, or other arguments for intervention linked to commercial, tourism, social, economic, sustainable development or urban requalification policies. This disconnection leads to a loss of knowledge of the functioning of the system that feeds the territory (Hedden, 1929) and the absence of the food issue from land use and territorial planning policies (Brand, 2015; Pothukuchi \& Kaufman, 2000).

The integration of agricultural and food issues into planning problems is more specifically structured in the field of research and action of Urban Food Planning that developed in the 2000s in North America and Northern Europe (Brand, 2015; Morgan, 2009). The report's terms show the sudden awareness of a missing piece by the world of urban planning practitioners and researchers: "a puzzling omission" (APA, 2007), "the darkside of urban dwelling" (Wiskerke \& Viljoen, 2012), and "this intellectual lacuna" (Morgan, 2015). Facing the "new food equation" (Morgan, 2009) that prevails in urbanized areas and especially in metropolitan areas, the objective is to rethink the place of planners in the functioning of agriculture and food, and to reintegrate them into the mechanisms of production and organization of spaces, especially urban and metropolitan. More recently, concepts and terms have emerged on the international scene that reflect this ambition to rethink these complementarities: "Sitopia" (Steel, 2009), "Continuous Productive Urban Landscapes" (Viljoen \& Bohn, 2005), "City Region Food System" (FAO-RUAF), and "agro-ecological urbanism" (Deh-Tor, 2017).

The notion of "Continuous Productive Urban Landscapes" seems to us particularly relevant insofar as it renews the modalities of analysis of the interactions between living space, food and agriculture. The resulting notion of "foodscape" (Buyck \& Courcoux, 2019; Toublanc \& Poulot, 2018) will serve as a methodological framework for our research. We will therefore consider the city not as an inhabited built-up area but as a landscape of activities, notably food activities. Agro-ecological urbanism is also of particular interest to us because of the change in values it brings about in the face of a neoliberal urbanization mode and because of the way in which its authors set out the paradigm of an alternative contemporary urbanism based both on a re-arrangement of the mutual interdependencies between city, agriculture and food and on an integration of the issues of equity and solidarity.

Here then lies our second hypothesis, focused on the question of the values that guide action. Following the work of Bruno Latour (Latour, 2017), we consider that ecological denial - intrinsic to contemporary agriculture, food and cities as well as to their dissociation - and social inequalities — be they food or urban — are one and the same problem. The sustainability of urban planning is therefore part of a quest for both ecological and social justice, that is, the introduction of new reference values for action.

\section{The beginnings of territorial food planning: the Grenoble and Caen agglomerations}

In France, Grenoble and Caen are medium-sized metropolitan areas. According to the INSEE 2016 legal population data, they bring together 160,000 and 108,400 inhabitants respectively (at the municipal scale); while Grenoble's population stagnated between 2006 and $2016(+1.3 \%)$, Caen's population fell by 4\%. In both cases, growth on a metropolitan scale is in fact attributable to the peri-urban ring, with a 
suburbanization phenomenon initiated in both cases from 1975 onwards, to reach metropolises with a similar demographic weight: 400,000 inhabitants for Caen la Mer and over 440,000 for Grenoble-Alpes Métropole (the two "Métropoles" have almost identical numbers of communes, 50 for Caen la Mer and 49 for Grenoble-Alpes Métropole).

In Caen, peri-urbanization is driven by the development of low-skill industries, contributing to the growth of a "red plain" eastern of the city (Rivière, 2009); contemporary dynamics are still concentrated to the east of the city centre but also to the south. Due to its lowland location and dense transport network, peri-urbanization spreads to more distant areas. Yet, Grenoble has to deal with a constrained site by three mountain ranges that have historically driven the dynamics of peri-urbanization, in the north-east, in the Grésivaudan along the Isère, and in the south of Grenoble, and finally towards Voiron, a small-sized city in the north-west. Peri-urbanization is associated with the consumption of space, sometimes carried out in the name of increasing tax revenues. As José Serrano (2005) points out, agricultural areas are valued for their environmental amenity for households seeking a "farm way of life", with a mission for farmers to maintain the landscape and fight against land abandonment. Nevertheless, competition between agricultural and residential uses on the land market and the effects of speculation are increasingly constraining agriculture.

This holistic progression of the peri-urban area, a type of space often despised (Billard \& Brennetot, 2009), particularly in terms of landscape because it is said to be of poor urban quality, is explained by the major changes within the agricultural sector in the twentieth century. The mechanization of agricultural production, the search for yield and the transition towards a commercial and disconnected agriculture (towards global and national markets) from the 1950s onwards have led to either land abandonment or the development of residential suburbs when the infrastructure allows it. Thus, in Grenoble, this phenomenon was marked on the right bank of the Isère river in the Grésivaudan (the wine-growing hillsides in the foothills of Chartreuse very quickly became one of the most popular residential areas in the agglomeration), or on certain foothills of the Vercors (Claix, Seyssins) or Belledonne (Saint-Martin-d'Uriage, Vaulnaveys-le-Haut). In Caen, the tradition of large-scale cereal cultivation on the plain is not a hindrance to the development of the suburban area, and agriculture is intensive and highly industrialized, with the port of Caen-Ouistreham, an export hub for agri-foodstuffs.

There is an imbalance in the way in which the food issue is taken into account between the two "Métropoles", even though they very early indicated the preservation of agricultural land as a priority in their planning documents. Grenoble is considered as a historical area in terms of peri-urban agricultural policy since the 1960s. Local products and short food chains have been mobilized as a condition for the preservation and development of peri-urban agriculture since the 1980s (agricultural programme for the urban region and creation of the Association promoting agricultural development within the Grenoble $\mathrm{Y}$ ( $\mathrm{Y}$ is referring to the confluence of the Isère and Drac rivers) named ADAYG in 1984). From 1997, the ADAYG took over the coordination of the "Taste Week" and contributed to the emergence of the food issue. The issue will gradually become part of the local agenda in the early 2010s as a result of participation in European programmes that contribute to a broader understanding of the food issue (notably by opening up the consumption side of the issue). The beginnings of a food 
strategy on a metropolitan scale became a reality in 2012 (Brand, 2015) and led in 2019 to the holding of the first food council of the inter-territorial food project (PAiT), which is an act of necessary cooperation on this subject between Grenoble-Alpes Métropole; the intermunicipal associations of the Voironnais, Sud-Isère and Grésivaudan; and the two Chartreuse and Vercors Regional Nature Parks.

In Caen, the construction of a territorial agricultural project is complex because of a tradition of field crops mainly for export. However, the presence of livestock and vegetable growing areas is an asset to support the diversification of the sectors and a better integration of local agriculture into the local market. Nevertheless, some farmers are involved in complex agri-food chains (Guillemin \& Marie, 2017): one farmer we met ensures his crops manually in a just-in-time process, from one day to the next, to supply the central purchasing office and the markets in Caen. Food emerges later on the agenda, but it emerges as an element that could federate a consensus on agriculture in the region; therefore, the 2014 SCOT proposes the development of crops for local supply in short circuits, on plots less suited to productivist agriculture (Guillemin \& Marie, 2017). In 2017, in the context of the creation of the Caen Normandie Métropole, a territorial food project plan (PAT) aims to make the food issue an element of added value for the territory (Esnault, 2017). The resulting PAT, which integrates both the issues of relocation of flows and consumption issues such as food insecurity, was thus awarded the 2018-2019 national call for projects by the Ministry of Agriculture and Food.

Finally, third hypothesis, we believe that the renewal of the links between city and food cannot take place without the implementation of new solidarities between, in and with the inhabiting communities. This third hypothesis therefore relates to the method implemented to bring about change, that of reconnecting agriculture, food and the city, and that of changing reference values. Citizen participation is indeed implemented in territorial food project approaches.

However, can we speak of agro-ecological urbanism? We propose to gauge this turning point through in situ immersion and to examine territorial food planning in the agglomerations of Grenoble and Caen. How is this urban agenda being implemented in the territories? In what context does it take place and how does it fit in with the current urban planning process? Such questions are themselves necessarily part of the vast reconfiguration of the tools and practices of urban planning, which is currently challenged by budgetary austerity, digital paradigm, ecological emergency and the new perspective on the knowledge of local populations.

\section{Revealing metropolitan food landscapes: the food-transect as a collective method of analysis and urban prospective}

In order to show the links and tensions that run through the spaces of the Caen and Grenoble metropolises, we chose to carry out in situ research that we can describe as multi-site (Falzon, 2009). The aim here is to retrace this choice and make it central to our investigation. As the coordinators of the issue of Espace et Sociétés devoted to multisituated research (Baby-Collin et al., 2018) remind us, multisituated research which is increasingly present in the field of social sciences - is based on the movement of researchers. Indeed, researchers follow objects, individuals, and plots in their expanded context of today's globalization (Marcus, 1995); they take different 
points of view in order to understand the object of study in all its complexity. This approach is to be linked to the spatial turn that is concomitant to it (Döring \& Thielmann, 2009). Based on a thought of the network and proximity, the spatial turn invites us to reconsider the way we look at space in order to seize social relationships differently. The relational dimension of space is central: the distant, totally interconnected with what takes place here and now, is sometimes found in proximity and phenomena of co-spatiality (Lussault, 2009) are often highlighted. In the same way, multisituated research emerges in the field of landscape at the same time as the crystallization of a way of thinking about landscape that is not so much related to sight as to how it is shaped by its inhabitants (Ingold, 2015; Jackson, 2003). It is therefore at the crossroads of these different currents of thought — multisituated studies, spatial turn and landscape as a field of activity - that we have constructed our methodological approach. The walks, in the form of transects, escape from contemplative passivity to take up a more dynamic position linked to the activities - agricultural, food or urban — that make up the places crossed.

\section{The transect, a method of analysis and prospective by walking}

Although walking is regularly convoked in space science pedagogy and research, it is nonetheless plural. Modalities and aims often differ. In landscape schools, walking is an unavoidable practice of landscape observation, and it is currently being revived through landscape mediation, participatory approaches and reflections on the links between landscape and democracy. Although practised less systematically in urban planning training courses, walking is nevertheless a recurrent subject and working method (Careri, 2017). Considered as a way of taking the measure of uses, it is often mobilized within the context of sensitive approaches. Here again, the challenges of participation but also the spatial turn of artistic disciplines contribute to its renewal. Directly resulting from these debates on walking, the transect, which is more generally part of a tradition of the links between walking and the map pointed out by O'Rourke (2013), is an in situ analysis of a territory, most commonly performed by walking, in order to better understand the relationships between phenomena in the urban fabric. According to live interviews with those we meet, we discover an area by observing its urban forms and uses. But the transect is not an isolated walk; it is practised within a group and is enriched by the confrontations of opinions that emerge from encounters along the route as well as spontaneous exchanges between team members. A prospective dimension quickly emerges from this dynamic; it is often a guideline for the exercise: observing a territory and thinking about its future. In situ and collective exploration of the transect also gives rise to a new representation of the territory. The transect often resembles a cross-section representing, through text, photography and drawings, the routes taken during the walks and the questions raised during this exploration. The restitution of these sections facilitates public debate on these issues. This method, inspired by the work of the Scottish geographer Patrick Geddes (1925) and more recently explained by Nicolas Tixier (2016), has given rise to various practical applications in recent years and transects have been developed in various contexts ranging from urban planning projects to scientific research (Pousin et al., 2016) and educational experiences. It is a transversal approach valued by schools of architecture but intrinsically open to other disciplines. At the crossroads of social, 
spatial and ecological issues, the transect is a singular approach where walking, information collecting and prospective debate are linked and whose representation moves away from the plan and the map to focus on the narratives of places.

The transect, an open methodology, is adaptable to many issues. In this case, the transects ${ }^{1}$ carried out are part of a more general research project on urban food landscapes - the PSDR4 FRUGAL Urban Forms of Food Governance. In this context, the participants therefore specifically focused their attention on the relationship between metropolises and food systems. "What will food look like in Grenoble in 2050?" was the question to which the Grenoble transects wanted to contribute. A similar question was formulated in Caen.

The FRUGAL project's transects are indeed an opportunity to analyse the urban issues related to food supply, but also the potential for food autonomy, the question of social accessibility to sustainable food and finally the environmental balance. Sustainable food (economically and socially viable, more respectful of the environment, health and cultural diversity) is at the heart of our investigation. In our view, the transect allows us to observe "in depth" the spaces crossed and the relationships that underlie them, revealing landscapes of activity that are, in our case, food landscapes. As sitespecific — or even multi-situated (Falzon, 2009) — research, these transects are a rare opportunity to question the places crossed, their proximity and neighbourhood effects, while taking into account the social dimension of the space and, more broadly, the status of research on the city and agri-food. In contrast to synthetic and modelling approaches, we opt for a relational approach suggesting that places and their users carry within them a narrative that is already there and that must be revealed.

\section{Collective exploration of the Grenoble and Caen agglomerations by food-transect}

In association with the research institutes, the main stakeholder in the PSDR FRUGAL programme is Terres en Villes, a national network of large French agglomerations and metropolises mobilized to maintain and develop urban and peri-urban agriculture. With the help of Terres en Villes, Caen and Grenoble have been chosen as the locations for the transects. It seemed to us technically difficult to implement the method in all the cities covered by the programme. It was also impossible to organize the transects in a unique city. It was therefore decided to organize one day of transects in each of the two regions involved in the programme. Being based as researchers in Grenoble, the organization of a transect in Grenoble then seemed appropriate and the Roanne ${ }^{2}$ option was postponed. For the Grand Ouest, we debated with the local researchers and Caen immediately appeared as a territory where the actors could easily be interested and driving forces; the transect was very timely to address food issues ${ }^{3}$. In both Grenoble and Caen, the idea was also to gather together researchers and actors mobilized in the Frugal context and to use these prospective and collective walks to produce a sitespecific synthesis of our approaches to different disciplines and interests. The

\footnotetext{
${ }^{1}$ The transects carried out in the FRUGAL project context could not have taken place without the invaluable help of Justin Bryant. The authors of this article would like to thank him warmly.

${ }^{2}$ Roanne has long held our attention for Rhône-Alpes, but the technical-political context proved in the end to be too unstable to support such an approach.

${ }^{3}$ In Caen, the transect method had not yet been used (unlike in Rennes, for example), and the city is just beginning to put food on its political agenda.
} 
preparation of the transects is a fundamental step, and the unresolved difficulties during this installation phase can be observed throughout the research: Where to walk? Who makes up the teams? How many teams/transects are there? What tools should be used to capture and transcribe the encounters with places and people? These are all questions that animate the debate and shape not only the form of the walks but also the content of the research. In this case, we have tried to mobilize a maximum of people by focusing on the diversity of the participants' profiles. We have therefore invited the people involved in the programme as well as the people and networks we met during our surveys. An invitation form was created and sent to this large panel of actors including civil society and the associative world. In the end, in Grenoble, it was mainly these actors who responded to our invitation and participated in the transects. In Caen, the associative world was less represented but the actors of the formal urban planning sector were numerous. As far as the routes, we determined them jointly. It was impossible to do this with all the participants because they were known far too late, but nevertheless a group of four to five people mixing researchers and actors worked on the question. The possible indications of future participants were also taken into account. As a result, four routes were drawn for the Grenoble metropolis and six for the agglomeration of Caen. These routes reflect the diversity of urban, agricultural and food situations. The number of routes was determined according to the number of participants in order to have heterogeneous groups of four to five people maximum. These teams were formed in advance to encourage multidisciplinarity within the team and homogeneity between teams in the same agglomeration. In regard to the number of participants, although six transect routes had been planned beforehand for Caen, only four were actually deployed on D-Day. Simple tools for capturing the atmosphere and situations were provided to the teams: a Dictaphone, a large map of the route to be followed specially made for the occasion, a roadmap with the list of team-mates, their contact details and directions to get to the starting point of the walk.

In Grenoble, we tried to determine routes (Fig. 1) that are complementary to each other and that, on the whole, traverse areas of great landscape and spatial diversity, thus reflecting the variety of metropolitan situations (Ambrosino \& Buyck, 2018), including the three valleys, the three massifs and the plain. In Caen, we reasoned in the same way and determined complementary routes between valleys and plains; between urban, suburban and industrial areas; between areas well connected by public transit and areas entirely devoted to the automobile.

In each team, a resource person (who participated in the elaboration of the route) helps to initiate the walk and the process. Very quickly, the group is completely autonomous. One of the missions of the resource person is also to ensure the implementation and definition of the protocols for capturing places and situations. We opted for light equipment and adapted for long walks. Interviews or atmosphere recordings, sketches, photographs, and some videos were therefore collected. Each group set up its own protocol.

If each team followed a route that had been given to them beforehand, nothing of course prevented them from adjusting it as they walked, i.e. making detours, shortcuts and stops. Thus, the different teams passed through very different areas from one another: agricultural, industrial, commercial, peri-urban areas, underprivileged neighbourhoods, abandoned shops etc. No place was found to be without interest. Even the most ordinary environment is equally favourable for the investigation of the 


\section{FOOD-TRANSECT DE GRENOBLE-ALPES MÉTROPOLE}

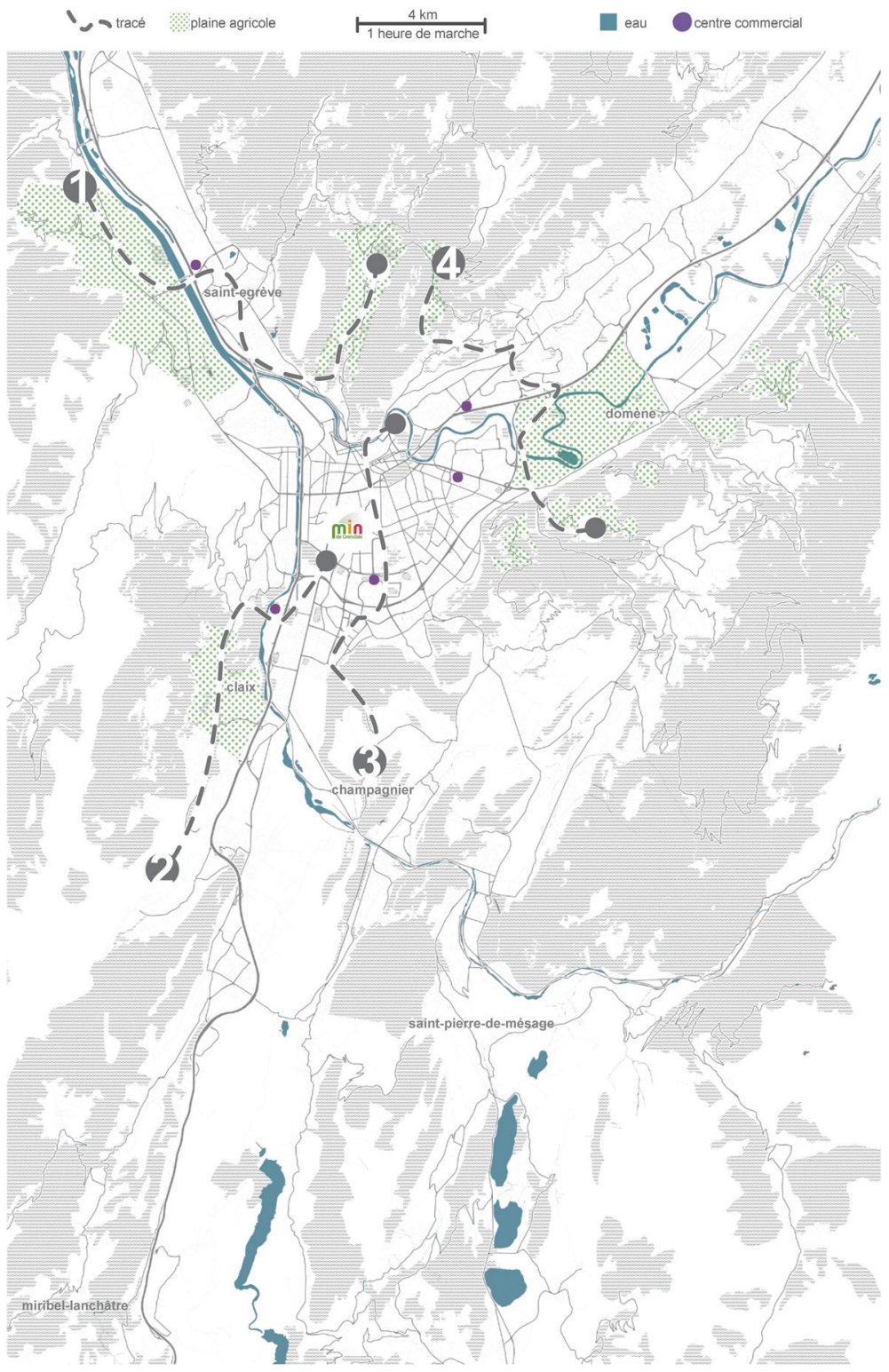

Fig. 1 Routes of the Grenoble transects. Source: IGN, Realisation: Justin Bryant

transect (Fig. 2). These long walks of 7 to $8 \mathrm{~h}$ (between 10 and $15 \mathrm{~km}$ ) allowed the groups to cross many places, to meet each other, to get to know each other and to have in-depth discussions on the food issue.

The comment most often spontaneously made by the participants of the transect, a collective exploration of the site, was "I learned a lot". The modality of movement - 


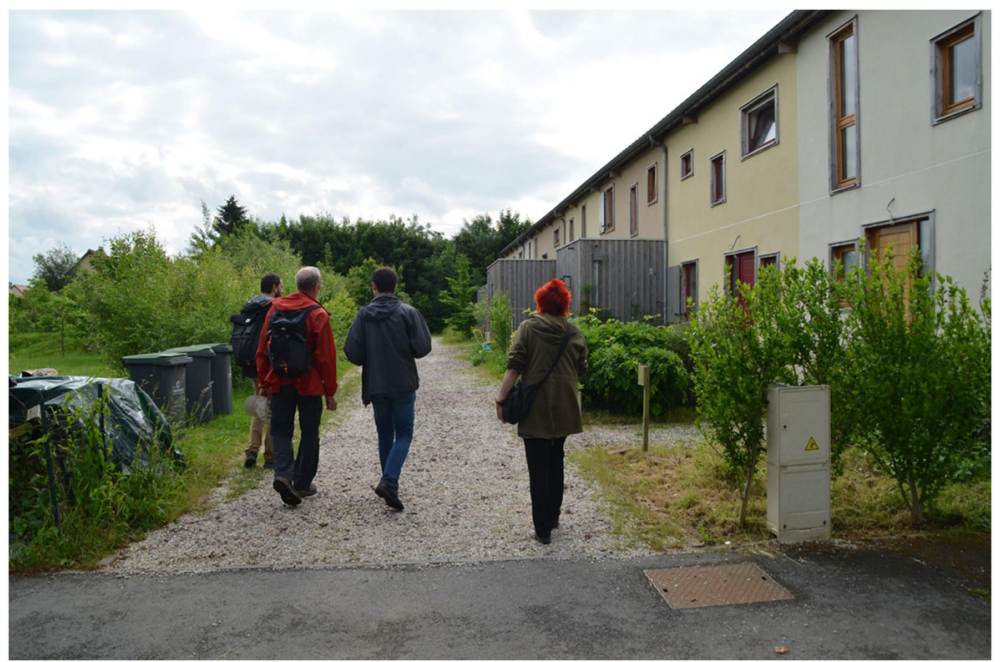

Fig. 2 Photograph of one of Caen's transects in the process of being made. Source: Frédérique Salmon

walking - certainly changes the focus of the attention. Often these journeys are made, sometimes regularly, but never on foot. The experience of being in a group also changes perception, all the more guided by a singular question and, what is more, with the injunction to encounter places and people 4 . This is because the encounter behind each of these walks arouses emotions and the other, like the place, only exists "when it provokes an emotion and this emotion obliges us to revisit our analyses and perceptions to discover the meaning of this difference" (Thomas, 2007: 16). Walking leads to the emergence of a different knowledge of place. Thus, even if the spaces we walk through are known beforehand, it is a major discovery. A landscape that is considered banal then becomes an object of astonishment charged with singularities. Tim Ingold describes this sense of discovery by comparing two methods of walking (Ingold, 2015): one in which intention guides movement (as in most of our daily journeys from one place to another), the other in which attention governs (as in the case of transects, where it is the act of taking the measure of the place that prevails). As mobilized in the transects described above, walking is then an experience of spatial displacement (Levy, 2008), both physical and cognitive (Muller, 2015).

\section{Ongoing collective debate about the place of food and agriculture in towns and cities}

The debate is permanent throughout the entire process, from the installation to the restitution of the transect. During the walks, debates were intense in each of the teams.

\footnotetext{
${ }^{4}$ As an example, one of the Grenoble teams chose during its transect to systematically ask the following questions to the people they met on their way: "Where do you shop? And in 50 years, where do you think you'll be shopping? What does agriculture mean to you in and around Grenoble? And in 50 years, how do you think it will have evolved? Finally, if you could make a difference, what would you do?

${ }^{0}$ For more information on the Grenoble transects, please visit this https://sites.google.com/view/foodtransectdegrenoble/home. For Caen, please visit this https://sites.google.com/view/food-transect-de-caen/ home.
} 


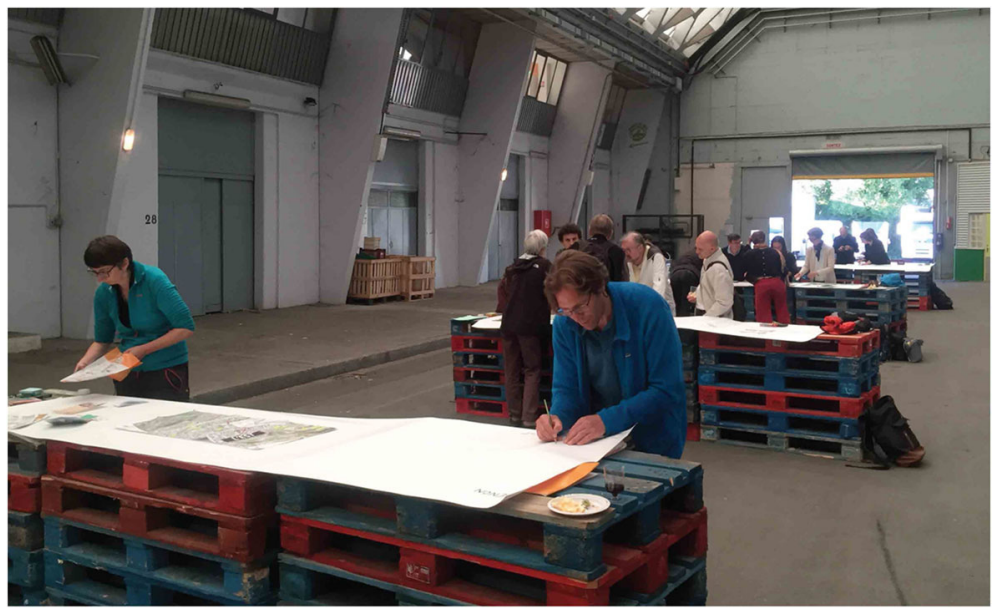

Fig. 3 Photography of the sections being made during the restitution to the Min of Grenoble. Source: Justin Bryant

This is one of the main differences with a methodology based on interviews. In the case of the transects, the analysis material is not a discourse correlated to one actor but to several, and already the terms of questioning are formulated collectively. At the end of these walks, the debates were extended and enriched as all the teams gathered at the Marché d'Intérêt National (MIN) for Grenoble (Figure 3) and at the Dôme, a centre of scientific, technical and industrial culture in Caen, in a convivial atmosphere to restitute the day's experience. During this major event, the teams transcribed on long white papers the cross-section of their journey. This section is composed of indications of location but also of in situ perceptions, elements of debate, prospective scenarios, documents collected, and captured atmospheres. Once the participants have drawn the sections, the teams present their work to the other participants and to the public who have come specifically to hear them. To this end, they rely on their large cross-sections, highlighting singular problems and a debate begins as a result of these presentations.

The cross-sections are then carefully archived, digitized and cleaned. In this context, we have transcribed them in order to make them accessible to the greatest number of people. The sections are now available on two websites ${ }^{5}$ where the collected metadata are also accessible (sounds, photographs and synthetic restitution of the section). Finally, at the end of June 2018, a research seminar was also organized to interpret together, using methods inspired by design thinking, the results obtained in Grenoble. In other words, three levels of analysis are superimposed and are articulated here: one "à chaud" (hot), i.e. in vivo and in situ within each team during the transects, the next one " $a$ froid" (cold) during the inter-team restitution and the sharing of the collected data, and finally the last one "réchauffée" (warmed up) from the graphic retranscription of the food landscapes in the form of annotated sections. What these analyses highlight are systems of solidarity, dependencies and responsibilities, which are often informal and sometimes tinkered with.

\footnotetext{
${ }^{5}$ For more information on the Grenoble transects, please visit this https://sites.google.com/view/foodtransectdegrenoble/home. For Caen, please visit this https://sites.google.com/view/food-transect-de-caen/ home.
} 


\section{Critical perspectives emerging from food-transects: bringing disconnected sustainable urbanism down to earth}

While the planning approach often works by characterizing large ensembles, the contribution of transects lies in the possibility of shifting the gaze by observing "in depth" the urban space and the relationships that underlie it. By reaching out to the inhabitants, users and stakeholders of the Grenoble and Caen conurbations, the multisituated approach of transects as described above brings us to the heart of the complexity of the relationships between food, agriculture and inhabited spaces. Two main dynamics emerge in the end from the analysis of the transects and the networks of interdependencies that they transcribe; the first is based on the phenomena of disconnection and standardization of contemporary urbanization as well as so-called sustainable urban planning at work in their relationship to food and agriculture, and the second transcribes the holds from which urban planning could gain in sustainability - landing - by taking up agricultural and food issues from new values and methods. These approaches, of course, do not claim to be exhaustive and are to be understood as questions arising from projects already in place — met in situ and/or developed during the experience of transects - addressed to our planning system, its tools and its actors.

\section{Reading food landscapes and revealing the dependency effects}

The first of the Grenoble transects, whose route to the west runs from the Chartreuse to the Vercors, crosses small farms as well as city entrance areas, and questions the use of unevenly invested gardens. What this cut shows is part of what could be described as food pragmatism in the face of socio-economic injustice. The food trajectories of people we met are described and we can see their close link with socio-cultural trajectories and the location of the place where they live. The way in which each person develops tactics to improve his or her diet (whether in terms of economic autonomy, ecology, meaning etc.) at his or her own level - that of those close to him or her as well as that of a neighbourhood network - is also striking. These financial, cognitive or relational adaptations also highlight changes over time, whether it be nostalgia for the standard of living in the 1970s (as witnessed by the farmer) or the projection towards 2050, which is however close to a return to the past (mention of a form of neo-feudalism).

Transect Grenoble 1: "West”, Source: J Buyck, P-A Landel, C Durand and M Neilson. Realisation: J Bryant.

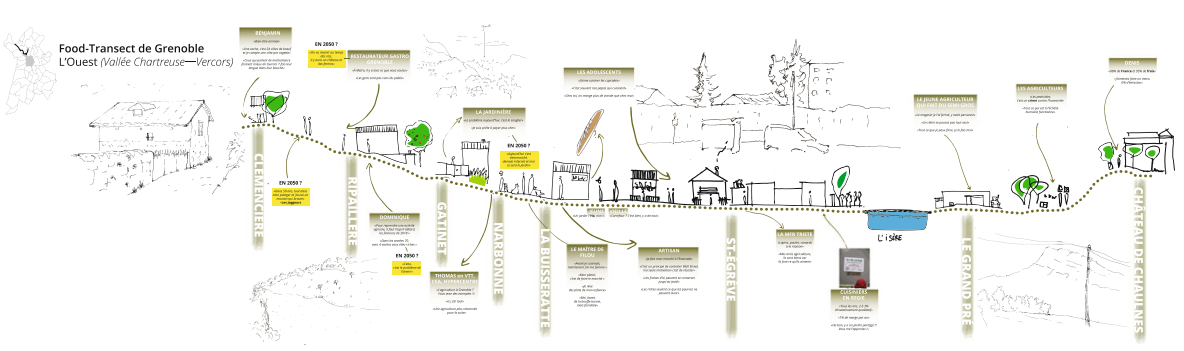


The second transect is located in the south of the Grenoble metropolitan area and runs from Vif to join the National Interest Market. Throughout this cup, the participants travelled through peri-urban spaces of great diversity between residential areas, wastelands and fields. The future and sustainability of urban fields was widely questioned, as was the predominance of the development of ornamental green spaces. Nourishing resources are considered invisible to the eyes of developers (the slope's enfranchisement, future urban extensions announced on the fields and the dichotomy between large commercial areas and "food deserts" in residential areas) and the efforts of vegetalization appear "above ground", as evidenced by the cherry tree in the middle of the traffic circle or the beautification of the housing estates mentioned by the gardener. The result is a general questioning of sustainable urban planning through the prism of food for all, all the more so as certain practices, such as picking, are neglected.

Transect Grenoble 2: "South”, Source: N Bertrand, E Roux, J-M Roux, J Rigolot and L Agier. Realisation: J Bryant.

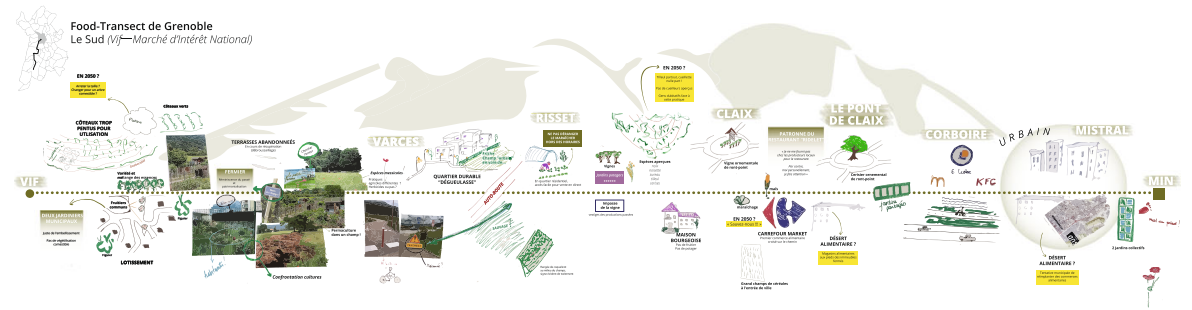

The third of the Grenoble transects is oriented North-South and joins the Champagnier plateau and the city centre. This time, the focus is on natural resources in the face of urban expansion. The competition between periurbanization (and related uses, especially recreational) and agricultural uses is striking, as is the dichotomy between windy markets and "mineral" mass distribution (the slab of Grand Place). The well-known problems of land pressure with a sustained pace of construction (mention of the one hundred building permits allocated) and urban sprawl are raised. The desire to live in the country is confronted with the realities of the land and the hybridization of imaginations presented as a vector for reinventing food.

Transect Grenoble 3: "North-South", Source: B Pecqueur, M Martin, A Kali, S Chamot and M Dallet. Realisation: J Bryant. 


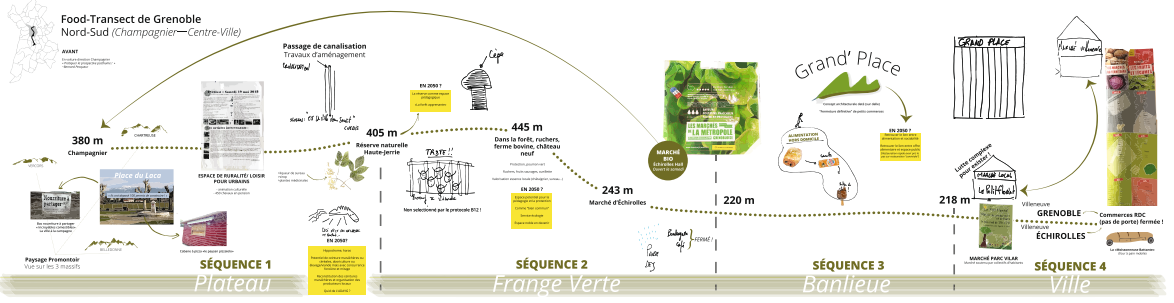

The fourth transect is located in the East and connects the Belledonne massif with the Chartreuse mountain range. There, it is the solidarities beyond food systems, relatively disembodied, that emerge from this exploration crossing a wide variety of spaces from production (between livestock and vegetable gardens) to mass distribution through the university domain. The disintegration of sectors is described, as is the fragility of small producers and the multiplicity of intermediaries. Junk food is discussed, and its offground and automated nature is highlighted. Between parking lot, road and lawn, the description of a sterile territory, mostly waterproofed, is described. Here again, the doit-yourself approach to food choices and food supply is striking, as is the mutual aid (barter) and experimentation (especially in public spaces) at all levels of food trajectories. It is also in this section that the question of gratitude for quality food is addressed and more generally the link between food, health and well-being.

Transect Grenoble 4: "East”, Source: J Bryant, C Brand, G Jourdan, C Bordenave. Realisation: J Bryant.

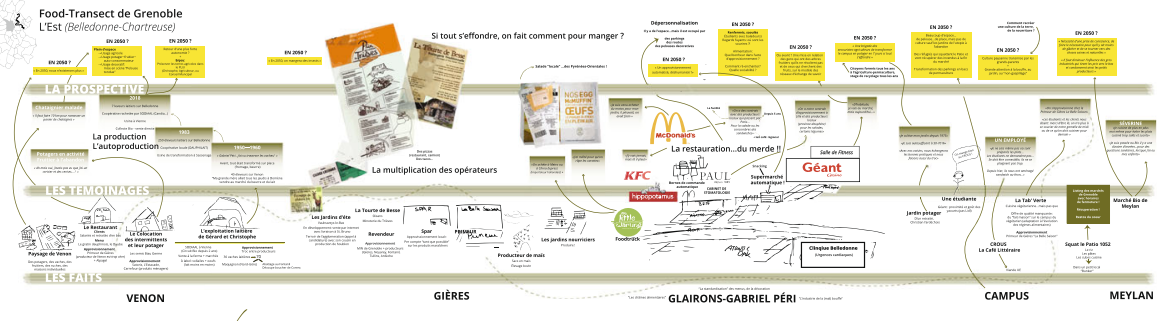

In Caen the routes all have the same finish point. They are thus distinguished by the location of the departures. The first of the sections starts from the Verson Center and crosses "dormitory" towns, recreational and productive areas (including cereal monoculture and market gardening). The cohabitation of conventional and alternative marketing channels is also visible. The pavilion is described there as a food desert, the place of the animal in question (the horse whose use is recreational in relation to the cow and its feeding functions) and numerous architectural reconversions transcribed (old farmhouse that became "AMAP" association, a mill that became a kayak base). An example of a self-constructed eco-neighbourhood is highlighted, particularly in its 
dimension of food innovation. This raises the question of the self to reappropriate the food in a rural suburban area.

Transect Caen 1: "Verson city centre", Source: M Marie, J Duval, P Mazerand, F Salmon, M T Savigny and C Teissèdre. Realisation: J Bryant.

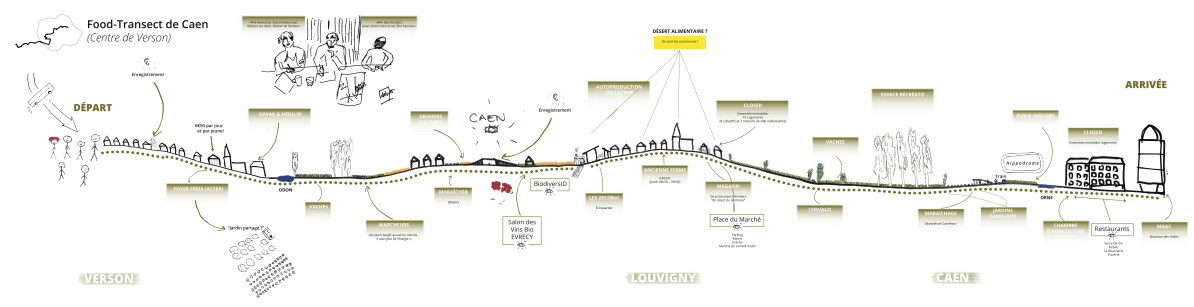

The second of the transects, the one starting in Bénouville, questions the visibility of the food chain and the cohabitation of models in the landscape (particularly the disappearance of small businesses and the economic concentration of the distribution sector). Particular attention is paid to processing and distribution, including that in the form of school canteens, whose supply channels are singular, and this at different scales. What is the potential for connection with the territory? The organic sector appears in this section, in opposition to a landscape of the food industry, coupled with ornamental plantings, and with a significant influence in terms of space and presence along the chain.

Transect Caen 2: "Bénouville", Source: A-S Boisgallais, F Carette, U Legentil, C Bretin, S Valognes and M Esnault. Realisation: J Bryant.

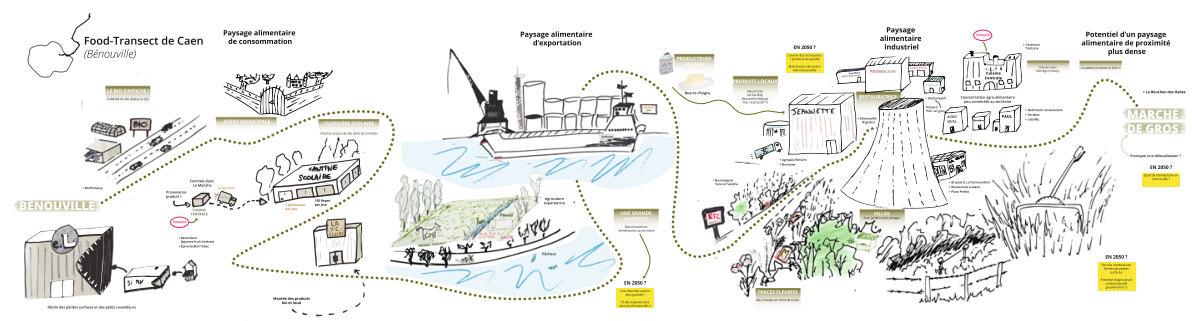

The third transect from the Sucrerie de Cagny shows fragmented food landscapes between agro-industrial systems (sugar factory, beet and flax fields, shopping centre and "restaurant village") and town centre habitats, and their associated sourcing practices, depending on the populations encountered. It reveals the contradictions and paradoxes of cohabitation. Social selectivity and food justice are at the heart of the transcribed debates. From a spatial point of view, the Orne seems to act as a frontier 
between, on the one hand, food dependent on the food industry and fragmented choices, and on the other hand, quality, organic and healthy food.

Transect Caen 3: "Cagny sugar factory”, Source: J Bryant, A Braun, F Kuntz, P Madeline, V Robert, P S Lebrun and S Bonnefoy. Realisation: J Bryant.

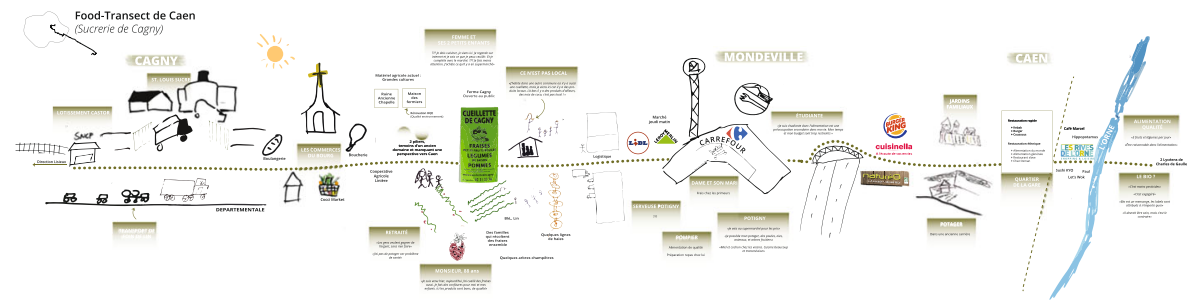

Finally, the fourth transect - starting from Biéville Chateau, questions the future of urban suburban forms. Suburban areas are mainly crossed, but also leisure spaces (golf, typical equipment of peri-urban spaces) and large plots of intensive cereal production. The future of food in rural suburban areas is particularly questioned, especially with regard to the expansion of suburban areas but also lifestyles (lack of grocery stores or local markets, aging population, dependence on cars, use of gardens etc.). These areas are also addressed through a regulatory approach (area to be urbanized, public policy on gardens led by the mayor), without mentioning, however, the densification of buildings.

Transect Caen 4: "Biéville Chateau", Source: J Buyck, A Diouf, C Duplessis, M Godefroy, P Guillemin and A-S Valroff Strippe. Realisation: J Bryant

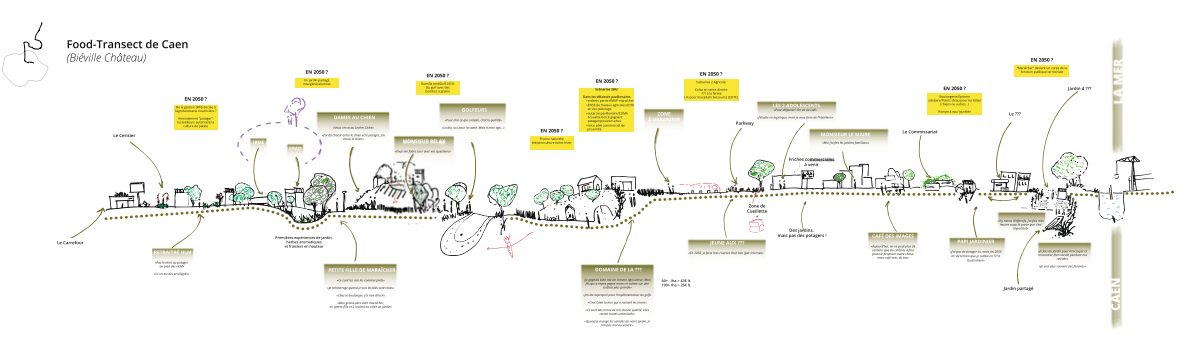

\section{Disconnection at the heart of sustainable urban planning}

The analysis of the eight transects produced in Grenoble and Caen shows, in a context of urban sprawl and fragmentation, the changes in urban food supply and agricultural production towards ever greater concentration and industrialization. A logic of production, processing and local supply, based in part on a peri-urban agricultural and market gardening belt, is being replaced by a globalized logic, based on the agri-food industry and mass distribution, which is spatially reflected in the urban fabric (logistics and 
processing areas) as much as it is conditioned by the recomposition of urban systems (metropolization, transport) and the objectives of sustainable development (green and blue corridors, densification, public transport etc.).

\section{Standardization and disconnection at work}

The logics of neoliberalization of urban production and industrialization of agriculture generate a standardization of the food system but also affect the nature of the urban (by essence dense but also diverse) and of agriculture (ideal of a diversified agriculture for food self-sufficiency and landscape quality). This standardization is reflected in the concentration of the different links of the sector, resulting in a disconnection from producers and consumers, as well as from the territory with off-ground logics. Urban planning at work has very little influence on this, and even accentuates this trend.

Within the sector, we are witnessing a simultaneous phenomenon of concentration and disconnection at certain levels of the chain. Small producers and distributors are weakened in both cities, which is reflected by a feeling of abandonment (transect 2 Grenoble), the projection of a neo-feudal future based on a single-family operating system (transect 1 Grenoble) or the concentration of distribution by large groups (transect 2 Caen, transect 3 Grenoble). This disintegration seems all the more visible at the distribution stage, as a farmer from Belledonne (section 4 Grenoble) testifies: he evokes the sale of surplus milk production (milk, butter...) on the markets by his parents and grandparents, then, following the decrease in the number of farms, he observes a distance from the marketing channels (cooperative in Sassenage, in the Grenoble urban area, then the SODIAAL factory of the Candia group in Vienne).

The effects of specialization of agricultural production, whether intensive monoculture or niche agriculture (especially organic), can lead to a disconnection between farmers and consumers. The latter can generate misunderstandings about the missions attributed to agriculture in terms of landscape maintenance, with a standardization of the landscape and a loss of rapport with the soil in the case of field crops intended for export (section 2 Caen), or misunderstandings about the feeding function with an organic label, a guarantee of quality but socially selective food (section 1 Grenoble). The standardization of a low-quality food offer shows a disconnection from the land, both in terms of production and consumption (as evidenced by transect 3 Grenoble and its "lack of conviviality"). This disconnection with the ground is coupled with a cognitive disconnection in the representations that people have of the agricultural sector. For example, in transect 1 of Grenoble, the cyclist is stunned when questioned about the presence of agriculture in the Grenoble metropolis.

Despite the efforts of public authorities in terms of urban planning to take food into account (particularly through agriculture), the industrialization of production chains and the multiplication of intermediaries remain visible. The distance between the city and its granary is growing. Agro-ecological urbanism is not yet there.

\section{The shortcomings of "sterile" sustainable urbanism}

In the context of the inclusion of food issues in urban policies and the return of agriculture to the city (at least partially), representations of sterile development remain numerous. These include urban mineral forms, but also the misunderstanding 
surrounding greening and agricultural legacies, or finally the confrontations between productive and recreational uses.

The growing importance of mineral atmospheres in the agricultural sector and in places of consumption reflects a disconnection from the soil. Upstream of the sector, the spatial influence of buildings dedicated to the processing and distribution of agricultural products is particularly striking in peri-urban areas, especially in the case of Caen, which can be explained by the presence of a cereal plain and logistical infrastructures. The landscape to be seen is therefore that of the agro-industrial era, which also affects quality agricultural niches such as organic farming (section 2 Caen). In the case of Grenoble, while the distribution of large surfaces in peri-urban areas is still in the hands of large supermarkets, the mineralization of the sector affects the places of consumption more: in section 4 , the slab is assimilated to a sterile territory that dehumanizes both the agri-food industry and the urban environment. At the scale of the blocks, the structural evocation of the feet of neglected buildings (notably section 2 Grenoble) that housed food shops illustrates the impasse of the use of immediate spatial proximities, when they are not invested by networks of actors, leaving the inhabitants faced with a non-choice of food.

Sterile urban planning is paradoxically associated with greening, a misunderstanding that excludes nourishing functions. The markers of agriculture are made invisible by the use of aesthetic greening in production and consumption areas. Ornamental green marginalizes the nourishing vegetable garden (Marie, 2019), which is explained by the peri-urban dynamics and the suburban morphology present in both terrains. The residential suburban model considers "natural" spaces at the service of the built environment, as a landscape setting, in order to promote a peri-urban type of habitat and lifestyle. The poverty of this urban planning is striking in the housing developments crossed during the transects in Caen and Grenoble, where green is considered either as a reserve for urbanization, an extension zone, or in a cosmetic way, in the service of the dominant peri-urban model. The typical viary grid of these spaces (traffic circles) is occupied by "above-ground" plant forms (section 2 Grenoble), which give rise to a fantasized discourse of "nature in the city". Along the roads, nature appears to be shaped by this representation, as evidenced by the observed absence of poppies in the fields along the roads (section 2 Grenoble), or the sporadic presence of a few flowers (section 2 Caen). At the scale of the allotment, edible species are ignored. Vegetable gardens are indeed very unevenly invested, or even absent (section 2 Grenoble, section 2 Caen), which is justified by some inhabitants encountered by their peri-urban lifestyle (example of the dog that takes precedence over the garden, section 4 Caen). This trend even affects former farmers, as evidenced by a retired horticulturist (transect 4 Grenoble) who emphasizes the lawn surrounding his property more than his backyard vegetable garden.

The disconnection between agriculture, food and urbanized spaces also manifests itself on the cognitive level, via legacies, memory of places and vernacular knowledge that has been erased or little invested. These traces of past agricultural and food practices are the source of sterile representations among urban and peri-urban populations as well as planners, whether it is a lack of knowledge of agricultural professions, the origin of products or a system of values. For example, in transect 4 in Grenoble, the presence of a cherry tree loaded with fruit was obscured by members of a shared apartment building met by the transect walkers before the latter mentioned it. Apart 
from this individual echelon, one will also note a disillusioned discourse on the perception of quality by the guests and an ignorance of the origin of the dishes provided by the staff of the University restaurant in the same cup. From a landscape point of view, the toponymy of certain places remains impregnated with agricultural heritage (transect 2 Grenoble) but is diverted from its initial meaning since it is attached to a purely residential urban planning framework.

Finally, the hybrid nature of nearby peri-urban spaces feeds the confrontation between recreational and agricultural uses. The diversification of the farming profession towards public reception functions (AMAP, educational farms etc.) is a major factor in the development of the agricultural sector. The horse, animal characterized by an ornamental character, catalyses this challenge in Grenoble as well as in Caen. In transect 1 in Caen, cow breeding is confronted with equestrian leisure activities, similarly in Grenoble (transect 3) with the mention of 450 horses in boarding and the prospective projection on the stud farms and the racecourse.

In spite of the public authorities' investment in favour of local food, the reading of the sections resulting from the explorations underlines the sterility of the urban planning at work. From another angle, these sections raise the stakes of the Grenoble and Caen food landscapes, from production to consumption. Through emblematic figures of "disconnection", they describe the flaws in the current planning system. But they also suggest potential for renewal and avenues for work.

\section{Work paths to "land" sustainable urbanism}

Beyond this pessimistic observation, the analysis of the sections reveals potential for renewal: practices that bear witness to changes in progress and that would deserve to be linked to the usual practices of urban planning. These avenues, which have the potential for sustainability, translate into virtuous synergies that can promote the transition of agricultural, food and urban systems.

\section{Towards sustainable and nourishing urban planning}

Quality food is gaining visibility through the dissemination of alternative initiatives to the conventional food system that reflect a growing awareness of the quality issue in the agricultural and food chains (Goodman et al., 2012; Le Velly, 2017). Short-supply chains or specialized organic food distribution stores mark the sections, either through landscape markers along roadside infrastructures as on transect 2 Caen or through the mention of the adaptation of the restaurant with the " 0 emissions" menu (transect 1 Grenoble). This could be one of the objectives of sustainable urban planning: encouraging the development of a quality food offer, acting on the food landscapes of the territories. However, in order to get out of the social selectivity that these changes entail, urban planning must not fall into the trap of a concomitant integration of food justice issues (as defined by Allen, 2010 and Gottlieb \& Joshi, 2010). When the literature on these issues points to the need to act on the structural causes that shape food inequalities, urban planning is indeed concerned (Hochedez and Le Gall, 2016).

At the industry level, the market share of organic food is increasing (Agence Bio / Spirit Insight, 2019), hence the increased visibility of organic food stores in the town centres as well as in the suburban areas (Transects 2 et 3 Caen), stimulated by social 
expectations, or even the transition of former traditional food industries towards quality (example of the Jeannette cookie factory, transect 2 Caen). Certain urban figures also appear as centres for the diffusion of agricultural and food resources, such as the Louvigny eco-neighbourhood (Transect 1 Caen): residential, agricultural and food functions are in full synergy there, via the conversion of a former farm into an AMAP, the presence of vegetable gardens, and a local associative fabric. This virtuous circle makes this eco-neighbourhood an island of resources that also provides a supply function for other residential areas. This contributes to creating an agri-food network between the different housing estates. Ensuring complementarities between small market garden production areas, supply and distribution areas, and housing, through multifunctionality, helps give substance to the sometimes overly generic idea of sustainable urban planning, of which eco-neighbourhoods are among the most visible but also the most criticized representations.

The integrative potential of forests and gardens raises questions about their functions of individual and collective food self-sufficiency (Poe et al., 2013). These two areas participate in the reactivation of a base of values and practices, bringing them closer to new nourishing commons (Orstrom, 1990), which would lead to a form of citizen reappropriation of food production and distribution systems (Bouré, 2017). In Grenoble, as in Caen, the forest is unanimously invested with nourishing potential, both through the complementarity between crops and the reactivation of know-how that makes it a conservatory. Agroforestry is recognized as a lever for the future in Caen (transect 4) but already exists in Grenoble, although unequally invested (transect 3). The forest would then be a crucible for the coexistence of production, supply (via harvesting) and, more broadly, ecosystem services (carbon sinks and environmental education). On the other hand, the role of gardens seems more ambivalent in relation to their potential as a source of food (scales and populations concerned). In Grenoble, the multiplication of experiments in the form of vegetable gardens (shared, family etc.) is exposed to the risk of purely individual self-sufficiency and requires integration into the city's food system to avoid the pitfall of a large selective metropolitan garden (section 2). In Caen, investment is uneven and is emblematically reflected by the abandonment of former local vegetable gardens, which could nevertheless provide future potential through the recreation of a local food landscape. These are all places that could give rise to a localized renewal of sustainable urban planning.

Finally, downstream of the supply chain, the supply of agricultural and food products takes place through the exploitation of complementarities between different places in the city, sometimes giving rise to a form of "do-it-yourself", more or less formal, but not always reducible to marginal forms of supply, and more generally questioning the functioning of societies in transition (Chaléard, 2019). The potential for sustainability then lies in the adaptive capacities of households that tend towards the fertile city (as opposed to the city of food automatism, standardization or lack of supply...), capacities presented as a "solution" in the face of the collapse in Grenoble transect 4. Beyond the apparent opposition between mass distribution and alternative agri-food worlds, we observe combinations between supermarkets, markets and vegetable gardens, or even gleaning and picking, in the food trajectories of several households in Grenoble and Caen. The transects in Grenoble reveal a complementarity of markets in terms of segments (organic, supported by a collective of inhabitants, or conventional) and location (near the centre or in peri-urban productive spaces), which arbitrates in favour of a diversification of potential supply. 
Diversified assemblages are emerging in the food supply, mixing self-production by a vegetable garden and barter between neighbours (section 4 Grenoble), gleaning at the end of the market and supply to the Restos du Coeur, a non-profit organization providing free food to poor populations (section 4 Grenoble), or supermarket, market and picking (section 3 Caen). These combinations play on the time frame, particularly for market supply, and allow informal spaces to be linked to conventional markets, or even supermarkets and supermarkets.

The revival of food, agricultural (Lamine, 2015) and urban systems that we describe here goes far beyond denouncing the neoliberalization of the management processes of contemporary metropolises: while incremental initiatives (both individual and in the form of small collectives) are emerging in a context of unequal consideration by public policies, they also have to do with the ability to improve eating and living conditions in metropolitan areas. However, it is particularly surprising that no reference is made to public policies in favour of sustainable food or to planning mechanisms aimed at preserving agriculture, by the people encountered during these transects. This observation supports the disconnection of contemporary urban planning from its inhabitants.

\section{Towards meaningful, grounded and sustainable urban planning}

Reading the transects carefully, it appears that through agriculture and food, populations develop their attention to care, both in a quest for meaning and in an apprehension related to health issues (Brown \& Jameton, 2000). An approach based on food allows attention to be paid to this more intimate scale, whereas work linking urban planning and health identifies only leisure infrastructures and mobility systems as levers (Reyburn, 2010). At the local and even intimate scale, individual co-benefits are revealed among both producers and consumers. If changes in the agricultural sector undermine the viability of farms, the level of social ambition remains high and adaptation strategies (such as bi-activity, reasoned breeding) can result from an assumed choice, guided by a quest for meaning (as shown by the freedom associated with agriculture, "they do what they like", section 1 Grenoble). As for consumers, they express a "belly recognition" of the supply of quality products (transect 4 Grenoble). However, this argument linked to care is a little less visible in Caen, except for the growth of organic products in school restaurants (section 2). This question of care and well-being observed in the field of agriculture and food is not as such a component of sustainable urban planning, which focuses on soft mobility, thermal insulation or plant continuity. Such a change of values and thus of paradigm would revitalize the very meaning of planning practices and breathe new life into sustainability.

Agriculture and food also appear as ferments for education for individual and collective sustainability. This trend can be observed from an early age, as illustrated by the attention paid to the supply of quality products in school catering in Caen (section 2) or the grateful testimonials of the guests of a quality-oriented restaurant that opened on the Grenoble university campus (section 4). Agricultural and food-related know-how also form "conservatories" of good practices, which are circulating incrementally in Grenoble. Thus, to compensate for the ignorance of certain latent resources (e.g. cherry trees transect 4, or the lack of cultivation of cherry picking - transect 2) and the decline in individual processing practices (making preserves or reinvesting family culinary know-how), two solutions are emerging by 2050: promoting a learning forest (transect 3 Grenoble), a conservatory of 
edible foodstuffs and resources; and ensuring the growth of a network of exchanges and knowledge between populations who have resources and those who seek them (examples of fruit growers transect 4 Grenoble).

Finally, attention to ecology and respect for resources motivates the commitment of inhabitants to create more sustainable and resilient territories. Thus, the care given to self-consumption and the fight against waste (transect 4 Grenoble) demonstrates the concern of households to become part of a healthier ecosystem (Davies, 2019). At the subdivision level, eco-neighbourhoods only appear to be truly "sustainable" if they have a nourishing function like the Zecobat project in Caen, while the subdivisions crossed in Grenoble are perceived as a green guarantee, with no particular food function, of contemporary fragmented urban planning.

In the same way, it appears that the preservation of agricultural land in no way guarantees the sustainability of the urban and food system put in place. Indeed, it is not because agricultural land is protected that farmers will necessarily settle on it or grow healthy, local produce (see sections 1 in Grenoble and 4 in Caen). This observation runs counter to the territorial development policies in place today (notably through the protection of peri-urban agricultural land). As a reminder, there is no direct tool to influence the type of agriculture practiced. In this context, how can we encourage farmers on rich land near cities to develop an agriculture focused primarily on local supply when they often practice an agriculture focused on external markets, without direct link to local needs. Although, unlike in Caen, new installations are progressing in Grenoble, the profession remains difficult for farmers (transects 1 and 4 in Grenoble): all the farmers who came to sell their production to the market were very pessimistic about their future and/or that of their profession. In this respect, the link between territorial planning and measures to help farmers set up in business and access to land seems to be of prime importance, as is the need to take account of the soil and its qualities in town planning. And, more generally, this example is representative of the links to be built between territorial planning and inhabitants, users, an indispensable condition for the emergence of agro-ecological urbanism, a more anchored and grounded urbanism.

Through this immersion in the heart of the spatial relations between urban, food and agricultural, the disconnection to the ground, to places and to the inhabitants of these systems is confirmed. However, potential for the renewal of sustainable development practices emerges from this cross-analysis. These critical observations as well as the capacities for change question urban planning and more generally town planning. These are all privileged avenues of work for "landing" (Latour, 2017) the urban and contemporary urban planning.

\section{Conclusion}

This is what the transect crossing two medium-sized metropolises reveals. Contemporary urban planning, commonly known as sustainable urban planning, is - in many ways - disconnected. Disconnected from other fundamental issues of living, including food, food and agriculture are still too little grasped by planning and development. Disconnected from the inhabitants and their needs, the role of public and institutional actors seems to be underestimated and the conventional tools of urban planning are not recognized by the inhabitants. Urban planning is striking by its absence in exchanges 
with residents; it should be remembered that none of the people we met told us about its mechanisms. It seems disconnected from the ground and the geography of the place. With installations that continue to spread over arable land (particularly in Caen) and where the sometimes "ornamental" green wasteland is totally integrated into the urban fabric (particularly in Grenoble in terms of future eco-neighbourhoods), all these disconnections - thematic, procedural and geographical - call for urban planning to be brought down to earth, to reactivate its relational capacities, to give it back its values and to identify a common orientation and ambition for the health of soils and populations in a quest for ecological and social justice. The three hypotheses of this present work, that of the disconnection at work, of the values that guide urban planning, and finally that of the methods to be implemented by integrating the inhabiting communities, enable us to formulate work paths in this direction. These avenues of work, or potential for renewal and sustainability, reveal critical perspectives for a more nourishing, meaningful and rooted urban fabric. At the interface of food, agriculture and urban life, these potentials are capable of re-arranging both urban planning and each of these fields. Turning around urban planning, exploring its borders and interactions with food and agriculture, immersing ourselves in cities, and taking an interest in the infra, the micro and the narrative, we come to propose a disciplinary rethinking from its margins.

This overhaul of urban planning that we are calling for and whose beginnings we read through the transects is based on a relationship. Three projects seem to be essential to achieve this reconnection of urbanism: (1) Formulating new dialectics capable of inscribing a thematic renewal at the heart of the field of urban planning and ensuring a renewal of the values that guide action; (2) re-evaluating the processes of urban manufacture in order to weave links with the projects and needs of the inhabitants; (3) taking into account the singularity of places, spaces and geographies. The idea here is to steer clear of sustainable urban planning as a managerial or systematic paradigm in order to reactivate attention to themes, methods and places for a nourishing, meaningful and grounded urban planning.

With regard to the renewal of themes and values (1), the analysis of urban planning at work from the point of view of food has allowed us to envisage an alternative to this model of knowledge and action and thus to re-found the classical diptychs of the discipline. For example, the conventional urban/rural dialectic is largely supplanted (Florin \& Renting, 2015) by the challenges of agro-ecology and sustainable food. Could it not be replaced by the sterile versus fertile dialectic? Indeed, what our field immersions convey is indeed the dichotomy between ornamental vegetation (including some shared gardens to which one could attribute a nourishing function) and edible resources, but this observation extends well beyond the unbuilt spaces alone. On what condition could the line between sterile and fertile land be modified and thus bring out latent urban resources? On the other hand, the question of the quest for meaning has recurrently emerged. Through food, the intimate (through the recognition of the stomach, the education of the palate) is confronted with global issues and this is undoubtedly a formidable lever for change, solidarity and resistance. Finally, sociability versus immediacy are the terms of another important dialectic. Commensality leads us to reflect on urban temporalities in order to potentially reenchant sociabilities.

In terms of method (2), the experience of transects suggests that taking into account inhabitant practices and representations calls for an overhaul of territorial planning 
tools, processes and methods. As it works today, transects have shown that it is invisible and does not provide support for inhabitants wishing to bring about change. Conversely, the numerous citizen initiatives in favour of sustainable food that we discovered in Grenoble and Caen testify to a reticular, relational, incremental and fundamentally hybrid vision of sustainable urban planning. They are networks of solidarity and mutual aid in the face of the ecological and social injustices that impact residents both individually and collectively. These initiatives are not currently based on governance tools but on the establishment of relational proximities. These incremental initiatives are the matrix of an already existing project linking everyone with more global issues (fight against the collapse of biodiversity, food injustice...).

Finally, through this multisite approach, we are invited to pay renewed attention to places (3). Whatever their scale and location, they have a singular and crucial role in the sustainable future of agriculture, food and inhabited spaces. Here again, a priori determinations are delicate, but the plurality of locations and situations is a formidable potential for projects and sustainability, whether - as we have seen - on the scale of the dense city with rooftops, public spaces or parks, on the scale of the semi-dense city through agricultural reconquest or reconversion of large land areas, or on the scale of urban bangs where fallow farmland, suburban gardens, forests and agricultural belts are all places where agro-ecological possibilities can be reinvented.

Author contribution The authors contributed equally to the preparation of the paper.

Funding This research was funded by the FRUGAL research project (https://projetfrugal.fr/).

Availability of data and material The data that support the findings of this study are available from the corresponding author (JB) upon reasonable request.

Code availability Not relevant for this article.

\section{Declarations}

Competing interests The authors declare no competing interests.

Open Access This article is licensed under a Creative Commons Attribution 4.0 International License, which permits use, sharing, adaptation, distribution and reproduction in any medium or format, as long as you give appropriate credit to the original author(s) and the source, provide a link to the Creative Commons licence, and indicate if changes were made. The images or other third party material in this article are included in the article's Creative Commons licence, unless indicated otherwise in a credit line to the material. If material is not included in the article's Creative Commons licence and your intended use is not permitted by statutory regulation or exceeds the permitted use, you will need to obtain permission directly from the copyright holder. To view a copy of this licence, visit http://creativecommons.org/licenses/by/4.0/.

\section{References}

Agence Bio/Spirit Insight. (2019). Baromètre de consommation et perception de produits biologiques en France. https://www.agencebio.org/wpcontent/uploads/2019/02/AgenceBio-DossierdePresseBarometre2019.pdf. Accessed 8 Jan 2020. 
Allen, P. (2010). Realizing justice in local food systems. Cambridge Journal of Regions, Economy and Society, 3(2), 295-308.

Ambrosino, C., \& Buyck, J. (2018). The mountain metropolis's land design project. Grenoble, from plain to slope. Journal of Alpine Research, 106(2). http://journals.openedition.org/rga/4088. Accessed 8 Jan 2020.

APA, American Planning Association. (2007). Policy guide on community and regional food planning. https:// www.planning.org/policy/guides/adopted/food.htm.

Baby-Collin, V., Cortes, G., Bourdin, A. (2018). La recherche multisituée : méthodologies, démarches, objets. Calenda. https://calenda.org/467157. Accessed 8 Jan 2020.

Barles, S. (2010). Society, energy and materials: The contribution of urban metabolism studies to sustainable urban development issues. Journal of Environmental Planning and Management, 53(4), 439-455.

Bellows, A.-C., \& Nasr, J. (2010). On the past and the future of the urban agriculture movement: Reflections in tribute to Jac Smith. Journal of Agriculture, Food Systems, and Community Development, 1(2), 17-22.

Billard, G., \& Brennetot, A. (2009). Le périurbain a-t-il mauvaise presse? Analyse géoéthique du discours médiatique à propos de l'espace périurbain en France. Articulo - Journal of Urban Research. https:// journals.openedition.org/articulo/1372. Accessed 8 Jan 2020.

Billen, G., Garnier, J., \& Barles, S. (2012). History of the urban environmental imprint: Introduction to a multidisciplinary approach to the long-term relationships between western cities and their hinterland. Regional Environmental Change, 12(2), 249-253.

Blay-Palmer, A. (2008). Food fears. From industrial to sustainable food systems. Ashgate.

Bouré. (2017). Réappropriation des systèmes alimentaires par les citoyens : une logique de Communs urbains. Netcom, 31(1-2), 175-192.

Brand, C. (2015). Alimentation et métropolisation : repenser le territoire à l'aune d'une problématique vitale oubliée, Thèse de doctorat de géographie, Université Grenoble-Alpes, 656 p.

Brand, C., Bricas, N., Conaré, D., Daviron, B., Debru, J. et al. (2017). Construire des politiques alimentaires urbaines: concepts et démarches. Editions Quae, $158 \mathrm{p}$.

Bricas, N. (2017). Les enjeux de l'urbanisation pour la durabilité des systèmes alimentaires, in C. Brand, N. Bricas, D. Conaré, B. Daviron, J. Debru, L. Michel, C. Soulard (coord.), Construire des politiques alimentaires urbaines. Concepts et démarches, Versailles: Éditions Quae, 19-42.

Brown, K., \& Jameton, A. (2000). Public health implications of urban agriculture. Journal of public health policy, 21(1), 20-39.

Buyck, J., \& Courcoux, T. (2019). Economies, spatialités et urbanités du pain : Explorations dans la métropole grenobloise. In X. Guillot \& P. Versteegh (Eds.), Transitions économiques et nouvelles ruralités : vers l'émergence de métro-milieux (pp. 128-139). Publications de l'Université.

Careri, F. (2017). Walkscapes: Walking as an aesthetic practice. Culicidae Architectural Press.

Chaléard, J.-L. (2019). À propos de collectes et de collecteurs: un nouveau regard sur le monde. EchoGéo. http://journals.openedition.org/echogeo/17274. Accessed 8 Jan 2020.

Cummins, S., Findlay, A., Higgins, C., Petticrew, M., Sparks, L., \& Thomson, H. (2008). Reducing inequalities in health and diet: Findings from a study on the impact of a food retail development. Environment and Planning A, 40(2), 402-422.

Davies, A. (2019). Redistributing surplus food: Interrogating the collision of waste and justice. In N. Cook \& D. Butz (Eds.), Mobilities, mobility justice and social justice. Routledge.

Deh-Tor, C.M. (2017). From agriculture in the city to an agroecological urbanism: The transformative pathway of urban (political) agroecology, Urban Agriculture magazine, n³3, 8-10.

Döring, J., \& Thielmann, T. (2009). Spatial Turn : Das Raumparadigma in den Kultur- und Sozialwissenschaften. Transcript.

Esnault, M. (2017). Les flux alimentaires de la restauration collective. Mémoire de stage, Université de Caen Normandie. https:/projetfrugal.fr/wpcontent/uploads/2016/12/M2_morgane_esnault.pdf. Accessed 8 Jan 2020.

Falzon, D.-M.-A. (2009). Multi-sited ethnography: Theory, praxis and locality in contemporary research, Farnam, Angleterre, et Burlington. Ashgate Publishing, Ltd..

Florin, M., \& Renting, H. (2015). Building sustainable food systems beyond the rural-urban divide. Urban Agriculture Magazine, 30, 6-8.

Geddes, P. (1925). « The Valley Plan of Civilization » and « The Valley in the Town », in Survey, LIV.

Goodman, D., DuPuis, E., \& Goodman, M. (2012). Alternative food networks. Routledge. https://doi.org/10. 4324/9780203804520.

Gottlieb, R., \& Joshi, A. (2010). Food justice. The MIT Press.

Guillemin, P., \& Marie, M. (2017). La dernière exploitation maraîchère de Caen à l'épreuve de zonages contradictoires. Systèmes alimentaires / Food Systems, 2, 243-253.

Hedden, W. P. (1929). How great cities are fed. D.C. Heath and Company. 
Hochedez, C., Le Gall, J. (2016). Justice alimentaire et agriculture: introduction. Justice spatiale - Spatial justice. https://www.jssj.org/article/justice-alimentaire-etagriculture/

Horton, P., Banwart S.A., Brockington, D., Brown, G.W., Bruce, R., Cameron, D. et al. (2017) An agenda for integrated system-wide interdisciplinary agri-food research. Food Security 9 (2):195-210.

Ingold, T. (2015). Le dédale et le labyrinthe: la marche et l'éducation de l'attention, Intuitive Notebook \#2 Diagrams. Drawings and Spaces.

Jackson, J. B. (2003). A la découverte du paysage vernaculaire. Arles.

Knapp, J. G. (1930). How great cities are fed. by W . P . Hedden Review. The Journal of Business of the University of Chicago, 3(2), 263-266.

Kneafsey, M., Cox, R., Holloway, L., Dowler, E., Venn, L., \& Tuomainen, H. (2008). Reconnecting consumers, producers and food: Exploring “alternative” networks. Berg.

Lamine, C. (2015). Sustainability and resilience in agrifood systems: Reconnecting agriculture, food and the environment. Sociologia Ruralis, 55(1), 41-61.

Latour, B. (2017). Où atterrir? Comment s'orienter en politique. La Découverte.

Le Velly, R. (2017). Sociologie des systèmes alimentaires alternatifs. Une promesse de différence. Presses des Mines, $200 \mathrm{p}$.

Levy, B. (2008). Marche et paysage. Le rôle de l'expérience vécue. La Revue durable, 30, 23 -25.

Lussault, M. (2009). De la lutte des classes à la lutte des places. Grasset.

Malassis, L. (1997). Traité d'économie agroalimentaire. Les trois âges de l'alimentaire : essai sur une histoire sociale de l'alimentation et de l'agriculture, livre I, l'âge pré-agricole et l'âge agricole. Cujas.

Marcus, G. E. (1995). Ethnography in/of the world system: The emergence of multi-sited ethnography. Annual Review of Anthropology, 24, 95-117.

Marie, M. (2019). Estimation de la contribution de la production potagère domestique au système alimentaire local. VertigO, 19(2). http://journals.openedition.org/vertigo/26215. Accessed 8 Jan 2020.

Marsden, T., \& Murdoch, J. (Eds.). (2006). Between the local and the global. Confronting complexity in the contemporary agri-food sector. Emerald Group Publishing.

Morgan, K. (2009). Feeding the city: The challenge of urban food planning. International Planning Studies, 14(4), 341-348.

Morgan, K. (2015). Nourishing the city: The rise of the urban food question in the Global North. Urban Studies 52(8), 1379-1394.

Muller, Y. (2015). Le corps, la marche et la zone critique du paysage. Les chantiers de la création, 8. https:// journals.openedition.org/lcc/1096. Accessed 8 Jan 2020.

Noé. 2018. Fonctionnement biogéochimique et trajectoires des systèmes agricoles territoriaux français: flux de carbone, azote et phosphore (1852-2014), Thèse de doctorat en Biogéochimie, Université Paris-Sorbonne.

O'Rourke, K. (2013). Walking and mapping, Artists as cartographers. MIT Press.

Orstrom, E. (1990). Governing the commons: The evolution of institutions for collective action. Cambridge University Press.

Poe, M. R., McLain, R. J., Emery, M., \& Hurley, P. T. (2013). Urban forest justice and the rights to wild foods, medicines, and materials in the city. Human ecology, 41(3), 409-422.

Pothukuchi, K., \& Kaufman, J.-L. (2000). The food system. A stranger to the planning field. American Planning Association. Journal of the American Planning Association, 66(2), 113-124.

Pousin, F., Marco A., Bertaudière-Montès V., Barthélémy C., Tixier N. (2016). Le transect: outil de dialogue interdisciplinaire et de médiation, VertigO, Horssérie 24. https://journals.openedition.org/vertigo/17372. Accessed 8 Jan 2020.

Rastoin, J.-L., \& Ghersi, G. (2010). Le système alimentaire mondial. Concepts et méthodes, analyses et dynamiques. Quae.

Reyburn, S. (2010). L'urbanisme favorable à la santé : une revue des connaissances actuelles sur l'obésité et l'environnement bâti. Environnement Urbain / Urban Environment, 4, d1-d26. https://doi.org/10.7202/ 044886ar.

Rivière, J. (2009) Le pavillon et l'isoloir. Géographie sociale et électorale des espaces périurbains français (1968-2008). À travers les cas de trois aires urbaines moyennes (Caen, Metz et Perpignan). Thèse de doctorat en géographie, Université de Caen Basse-Normandie, 822 p.

Serrano, J. (2005). Quel équilibre entre urbanisation et préservation des espaces agricoles périurbains? Le cas d'une agglomération moyenne. Développement durable et territoires. https://journals.openedition.org/ developpementdurable/1605. Accessed 8 Jan 2020.

Steel, C. (2009). Hungry city. How food shapes our lives (2nd ed.). Vintage.

Sui, D. (2003). Musings on the fat city: Are obesity and urban forms linked? Urban Geography, 24(1), 75-84.

Thomas, R. (2007). La marche en ville. Une histoire de sens, L'espace géographique, 1, 15-26. 
Tixier, N. (2016). Le transect urbain. Pour une écriture corrélée des ambiances et de l'environnement in Sabine Barles, Nathalie Blanc (dir.), Écologies urbaines. Sur le terrain. Economica-Anthropos, PIR Ville et Environnement, 130-148.

Tornaghi, C. (2014). Critical geography of urban agriculture. Progress in Human Geography, 38(4), 551-567. https://doi.org/10.1177/0309132513512542.

Toublanc, M., \& Poulot, M. (2018). Les territoires agriurbains en Île-de-France: entre paysage ordinaire, paysage agricole et paysage alimentaire? Projets de paysage. http://www.projetsdepaysage.fr/fr/les_ territoires_agriurbains_en_le_de_france_entre_paysage_ordinaire_paysage_agricole_et_paysage_ alimentaire . Accessed $\overline{8}$ Jan 2020 .

Viljoen, A., \& Bohn, K. (2005). Continuous productive urban landscapes - Urban agriculture as essential infrastructure. Urban Agriculture Magazine, 15, 34-36.

Wiskerke, J.-S.-C., \& Viljoen, A. (2012). Sustainable urban food provisioning: Challenges for scientists, policymakers, planners and designers. In A. Viljoen \& J.-S.-C. Wiskerke (Eds.), Sustainable food planning. Evolving theory and practice (p. 598). Wageningen Academic Publishers.

Publisher's note Springer Nature remains neutral with regard to jurisdictional claims in published maps and institutional affiliations.

\section{Affiliations}

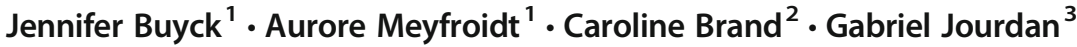

1 University of Grenoble Alpes, CNRS, UMR PACTE, Institut d'Urbanisme et de géographie Alpine, 14, avenue Marie Reynoard -, 38100 Grenoble, France

2 ISARA-Agro School For Life, 23 Rue Jean Baldassini, 69007 Lyon, France

3 Agence d'Urbanisme de la Région Grenobloise, 21, rue Lesdiguières -, 38000 Grenoble, France 